\title{
CIVIL-MILITARY RELATIONS IN DISASTER RESCUE AND RELIEF ACTIVITIES: RESPONSE TO THE MUDSLIDE IN SOUTHERN LEYTE, PHILIPPINES
}

\author{
Rosalie Arcala Hall and Anita Cular ${ }^{1}$ \\ The University of the Philippines Visayas
}

\begin{abstract}
This article examines engagements between civilian actors, the Philippine security forces and the US military during disaster response operations. The Philippine disaster framework recognises the military's role in disaster relief and has existing mechanisms for accepting international assistance and procedures for military-to-military cooperation in this task. The local authorities accord the military a central role in the disaster operations, contrary to notions of it being the 'last resort'. Tasking and coordination proceeded separately along civilian versus military lines, with limited interface between the two groups. The army reservists had greater linkages with civilian actors than did the army regulars, who dealt exclusively with the foreign teams. The US military's activities were confined to search and rescue and to providing critical logistics, which the Philippines actors lacked.
\end{abstract}

\section{Introduction}

On 17 February 2006, the village of Guinsaugon, St Bernard town in Southern Leyte, Philippines, was buried by a mudslide. The slope of the Mt Kanabag mountain range directly above the village fell and buried it under a slide 9 kilometres across and 30 feet deep. Of its 1857 residents, 154 were confirmed dead and 973 were entombed in this catastrophe (Office of the Governor of Southern Leyte 2006). The mudslide at Guinsaugon generated an unprecedented outpouring of national and international assistance. Civilian volunteers from nearby provinces and

${ }^{1}$ Dr Rosalie Arcala Hall and Dr Anita Cular are associate professors at the University of the Philippines Visayas. 
regions joined the local military units in the search and rescue operations that lasted almost two weeks. The mudslide was also one of the first cases where international military units joined search and rescue operations. A relatively large ground contingent of US Marines, diverted from the US-Philippine joint military exercises during that time, were among these. Because of the scale of the disaster, the Provincial Disaster Coordinating Council (PDCC), and not the St Bernard Municipal Disaster Coordinating Council (MDCC), became the focal point for the coordination of retrieval activities, relief provision and rehabilitation.

Although the Philippine military has been routinely deployed for disaster response, the way in which it relates with civilians (local authorities, government agencies and non-governmental organisations [NGOs]) also present at the site has not been fully examined. The presence of foreign military actors on the ground alongside local soldiers also provides an added nuance in examining military engagement with local civilian actors. As the event also marks one of the few times foreign military presence was factored into a disaster-coordination framework, it offers some key lessons on the dynamics and effects of such to a local community. Unlike international NGOs with clear grassroots linkages, foreign military personnel are agents of their government and therefore likely to elicit more sensitive reactions from locals. Moreover, given the already problematic nature of NGO-military relations in the context of humanitarian operations elsewhere, it is also likely that parallel tensions and difficulties will emerge in disaster relief operations.

This article probes civil-military interface in a disaster response using the 2006 mudslide at Guinsaugon village as a case. It identifies and describes how local, national and international actors worked and coordinated with regard to rescue and relief activities. It maps out networks of collaboration (for information sharing, access to resources, tasks and logistics) among those involved in the operations. It also examines the local disaster-coordination framework used and international norms on civil-military engagement, and discusses how these informed the behaviour of actors on the scene. Issues and problems of coordination, particularly between the military and civilian actors in this type of mission, are also presented.

The article is based on a research project undertaken by the authors from August 2008 to June 2009 under the University of the Philippines Systems Creative Writing and Research Grant. To draw up the list of institutional actors (government agencies, NGOs and military units) that responded to the mudslide, the authors reviewed minutes of meetings and reports by the National Disaster Coordinating Council (NDCC), the PDCC (Southern Leyte) and the St Bernard MDCC, as well as 
local news accounts of the event. Key respondents from the regional offices of the Departments of Social Work and Welfare (DSWD), Health (DOH), Environment and Natural Resources (DENR) and Public Works and Highways (DPWH) and the Tacloban City chapter of the Philippine Red Cross (PRC), who were present at the site two years prior, were interviewed. In addition, the St Bernard police chief, the former St Bernard town mayor and the former Southern Leyte governor (who were incumbents at the time of the disaster) and an officer from the armed forces of the Philippines (AFP) Security Engagement Board in Manila were interviewed. Two focus group discussions were conducted with 18 officers and enlisted men from the $8^{\text {th }}$ Regional Community Defense Group based in Maasin, Leyte, and with 21 officers and enlisted men from the $43^{\text {rd }}$ Infantry Battalion currently based in Iligan City. Both units were deployed in 2006 for the disaster response in St Bernard.

Because the research was conducted two years after the event, the authors were unable to interview any of the key foreign military personnel involved. Instead, they relied on official publications of the US Embassy in Manila (which covered the US Marines' activities at the site), reports of the St Bernard Police, accounts by local (Philippine) soldiers who worked with the foreign troops and local/national newspaper coverage of the disaster. This lack of firsthand accounts of foreign military involvement is an acknowledged limitation to the research.

\section{The military and disaster relief}

The armed forces of many countries are routinely deployed for domestic disaster relief. Often, owing to local human and logistical incapacity, the military is called in for emergency relief activities such as search and rescue, evacuation and provision of relief goods and services. However, such activities usually occur within defined parameters wherein the armed forces constitute a part of an intergovernment agency coordinative framework. While deployment orders strictly remain within the chain of command, the armed forces unit concerned (its personnel and assets) is tasked to engage civilian government units and authorities on a horizontal fashion. The number of military personnel and assets deployed is also normally scaled in line with the severity and extent of the disaster.

Unlike other types of internal/domestic missions, the military's involvement in disaster relief is seen by some authors as relatively uncontroversial. For Desch (1996:26), the military being engaged in disaster response does not generate unhealthy civil-military relations when compared to counterterrorism, law enforcement or social welfare. Because military deployment for disaster response is 
transitional by nature and subject to a strict timetable, this non-traditional task does not disturb the balance between civilian vis-à-vis military power in a democratic setting (Goodman 1996:40). ${ }^{2}$ That said, because disaster response (like other nontraditional roles) broadens military interface with civilian populations, the historicity of civil-military engagements in the disaster area (i.e. whether or not the area is a site of an active counterinsurgency campaign, or whether there are prior instances of collaboration between the local military and civilian actors) matters.

An integral component in analysing the military's role in disaster relief is the disaster response framework operative in each country. As said framework often anchors collective response to a civilian authority or agency, how these civilian actors utilise local and foreign military assets and, in turn, how the respective militaries deal with civilian direction in this operation type are at the core of democratic civil-military relations. Several aspects of this framework are worth examining: (1) the extent to which said framework identifies and stipulates the military's task in disaster response; (2) whether said framework invests authoritative decisions to a civilian agency or person to give orders and tasks to the armed forces; and (3) the extent to which the framework can accommodate and integrate foreign military assistance into disaster relief operations.

The military's engagement with NGOs in disaster response is a source of potential tension, given cultural and organisational differences. Mandel (2002) points to the dangers of 'militarisation' as relief organisations are edged out by better-equipped and mobile armed forces. Concern over the military's 'armed' credentials as state agents further lends political agenda to their presence, which runs counter to most humanitarian organisations' claim of neutrality. ${ }^{3}$ The idea that relief

${ }^{2}$ Goodman established three criteria in judging whether a task by the military leads to a healthier civil-military relations: (1) it does not crowd out civilian actors who can do the same job better; (2) it does not enable the military to gain additional institutional privilege; and (3) it does not veer the military away from its core mission.

${ }^{3}$ Emergency assistance arising from a natural or man-made disaster must nevertheless be differentiated from humanitarian assistance arising from conflict or political instability. In the latter, security is a key concern and the use of force (by the armed forces against attacks by non-statutory armed groups) is more imminent. International peacekeeping or peace support operations are also different missions where engagements between international NGOs, the local population and foreign military contingents on 
provision is being dovetailed with armed operations to serve broader counterinsurgency goals also creates tension with NGOs. Frerks (2008) observed that NGO-military engagement during the 2004 Indian Ocean tsunami, for instance, was characterised by parallel conduct of activities with intermittent information sharing. The sparse interface between the Indonesian military and NGOs was attributed to preconceived images of the former as human rights violators (Schulze 2005) and confusion over the normative principles supposedly limiting NGO involvement with any military (Wiharta, Ahmad, Haine, Lofgren \& Randall 2008).

Over the years, the military's increased visibility in providing humanitarian assistance during peacekeeping, peace support operations and other types of emergencies has prompted international efforts to establish norms governing such involvement. One such norm is the 1994 Guidelines on the Use of Military and Civil Defense Assets in Disaster Response (the Oslo Guidelines). ${ }^{4}$ The Oslo Guidelines confine military participation (by way of relief personnel, equipment, supplies and services) in these types of operations to disaster relief (excluding reconstruction and rehabilitation) and consider most appropriate for the armed forces the task of providing indirect assistance (one step removed from the population) and infrastructure support (as opposed to direct humanitarian assistance). The Guidelines also stipulate that assets should not be used to provide security to United Nations (UN) humanitarian agencies (as escort). Moreover, the Oslo Guidelines consider the utilisation of the armed forces as a 'last resort', that is, only when no comparable civilian alternative is present and where the military asset offers a unique capability that no civilian organisation can muster. The Guidelines set the following further conditions for the use of military assets: (1) that the affected state consents to it; (2) that assets are provided to the affected state at no cost; (3) that the military personnel deployed are unarmed and wear national uniforms; (4) that the foreign military units be self-supporting throughout their operation in terms of transportation, fuel, food rations, water and sanitation, maintenance and communication; and (5) that the use

the ground are far more complicated. In these types of missions, NGOs are careful to distance themselves from any armed forces to maintain their reputation as impartial actors.

${ }^{4}$ The Oslo Guidelines must be differentiated from the 2003 Guidelines on the Use of Military and Civil Defense Assets to Support UN Humanitarian Activities in Complex Emergencies (MCDA Guidelines), which cover military forces' participation in peacekeeping operations and humanitarian assistance in situations of conflict. 
of such assets be limited in time and scale, and must have an exit strategy. In terms of management of assets, the Guidelines further recognise the proprietary control of respective military commanders over these assets, and that requests for the use of such assets by UN humanitarian agencies and the affected state are decided on a case-to-case basis by the military commander.

Although non-binding to UN member states, the Guidelines offer normative guidance as to how affected and sending states ought to behave with respect to the use of foreign military assets in disaster response. To balance concerns, the Guidelines suggest that sending states consider seriously the cost-benefit ratio of deploying troops for this type of operation compared to other alternatives. In the same fashion, the Guidelines also assert that it is primarily the obligation of the affected state to provide humanitarian assistance to its own people, but that it should create a preparedness plan that includes receipt of international assistance as well as corollary procedures for accepting and using such foreign military assets. Among the responsibilities of the affected state vis-à-vis foreign military participants are overflight and landing permission, waiver of immigration documentation, exemption from custom duties, waiver of visa requirements, free access to disaster zone, recognition of certificate (to practice the profession temporarily), authorisation of transport and communication usage, and security of assets. The Guidelines also encourage states to enter or incorporate into status of forces agreements the parameters of receiving and using foreign military assets for disaster response.

Although seen as a 'last resort' and a temporary measure, the underlying sentiment of the framers of the Guidelines is that disaster response is not the military's rightful domain. Because military personnel are state forces, there are sensitive implications to their deployment in foreign soil. There is great pressure in these types of missions for the foreign contingents to distance themselves from the local population and where possible to dissociate the tasks they perform from their 'forceful' nature. Furthermore, although foreign military presence is only for a limited timeframe, there also is a premium to institutionalise parameters of engagement rather than rely on ad hoc rules. It also presupposes the subordination of military assets to a civilian and host government-led framework for disaster response. As in many cases of large-scale disasters, often the civilian apparatus is incapacitated, giving rise to a tendency where the military becomes the focal point of coordination activities by default. In these circumstances, civil-military engagements become problematic.

Philippine disaster framework and the armed forces 
The Philippine emergency-management framework rests on disaster coordinating councils (DCCs) as focal points for bringing together efforts by various government agencies at the local (village, municipal/city, provincial), regional and national levels. Each local DCC is chaired by the elected local chief executive (village captain, mayor and governor, respectively) while at the regional level, the Regional Police Commander acts as chair. The NDCC is chaired by the Office of Civil Defense Administrator (under the defence department) with the various department secretaries, including the Chief of Staff of the Armed Forces, as members. The tiered nature of DCCs assumes that the local DCCs are primarily responsible for disaster preparedness and relief, and that the national government through the NDCC only steps in when the scope of the disaster exceeds local capacity. In terms of financing, local government units (LGUs) and government agencies are mandated by law to set aside $5 \%$ of their annual internal revenue allotment and budget as funds to be utilised only for disaster-related activities. The Philippines has an existing framework specifying the procedures and arrangements for receiving international humanitarian assistance with disasters. The Memorandum of Understanding for International Humanitarian Assistance stipulates that the Philippines will only receive international humanitarian assistance under these conditions: (1) when a disaster or a major emergency occurs beyond the scope of the national government to handle; (2) after an appeal for international humanitarian assistance was made by the government; and (3) after the President has declared a state of calamity (Memorandum of Understanding for International Humanitarian Assistance 2007). Inked in 1990s, it tasks the departments of National Defense, Health, Transportation and Communication and Foreign Affairs and the bureaus of Customs and Immigration to facilitate the entry and movement of foreign search and rescue and disaster relief teams, and their accompanying equipment and supplies. Assistance by way of foreign military assets, in particular, are coursed through the Department of Foreign Affairs (through the military attaché), which in turn conveys such offer to the NDCC. The NDCC makes an assessment of needs and advises the President correspondingly to accept such offer. This type of international humanitarian assistance proceeds largely from a bilateral mode, where negotiations are between the host government/affected state and the contributing state.

There are problematic elements in the Philippine disaster framework. First, the framework is biased towards disaster response and tends not to enable parallel 
attention towards prevention, mitigation, preparedness and rehabilitation. ${ }^{5}$ Moreover, the capacity for forecasting, surveillance and monitoring is only sufficient for typhoons, flooding and volcanic eruptions, but not for other types of disasters. Given the regularity of such typical disasters, it has also been a trend for the calamity fund to be spent entirely on procuring food aid and providing temporary shelter to victims. Second, the framework features the centrality of government as actors, with NGOs and other private entities invited to participate but not necessarily given a seat at the decision-making table. NGO activities related to disaster are also highly regulated. Accreditation with the Department of Social Welfare and Development or its local equivalent is needed for them to operate in specific areas. NGO involvement in the Philippine disaster-management scene has been mostly in community preparedness but less in terms of relief provision (Lupig-Alced, Arcilla, Dulce \& Elegado 2005). Unlike other countries, the Philippines has no separate or dedicated personnel or assets for disaster response. The Office of Civil Defense (OCD) and its regional office act as secretariat for the NDCC and the Regional Disaster Coordinating Council (RDCC), respectively, but in terms of actual service, personnel and assets are 'contributed' by respective government agencies and LGUs. Because it is structured as a coordinating body, the NDCC and RDCC chairs have no authority to command government agencies to make their resources available for disaster response.

Within this DCC framework, the armed forces are just one of the many government agencies tasked to respond to disasters. However, it is a role the military has historically been involved in since the 1970s. From transporting people struck by calamities and delivering food and medicine during the Marcos era, the military has seen its disaster response role considerably expanded after 1991 (Hall 2004). Following Mt Pinatubo's eruption, the military became involved in reconstruction efforts (e.g. building the Lahar dikes as well as houses, classrooms and clinics in relocation areas). The National Disaster Preparedness Plan (1988) in particular confined the military's role to the emergency phase with the following tasks: (1) organising reaction teams in each installation; (2) establishing communication linkages and ensuring their availability during the disaster response operations; (3) assisting the police in securing the disaster area; (4) assisting in reconstructing

${ }^{5}$ In the literature, disaster response pertains to actions undertaken during emergency conditions to ensure safety and survival of the affected community. These include activities such as provision of relief, search and rescue, evacuation and temporary shelter (Carter 1991:58). 
damaged roads and infrastructure; and (5) assisting in providing transportation facilities for quick movement of relief personnel, supplies and evacuation of victims (Quilop 2008). When the NDCC later shifted to a cluster approach to disaster management, the AFP was assigned to the search and rescue, transportation and communication clusters. The cluster approach is envisioned to streamline coordination by limiting the number of agencies involved to do a common task.

Disaster response is spelled out as a mission area for the armed forces and constitutes a priority in terms of resource allocation and force deployment. ${ }^{6}$ However, compared to other mission areas, disaster response is considered secondary in terms of the actual expenditure devoted to it. Under the 2008 budget, a paltry 157 million pesos was allotted for disaster response, compared to 7.8 billion pesos spent on internal security (Quilop 2008). The military has little by way of assets devoted to disaster response. In 1995, the military refined its structure to enhance its capability for disaster response operations. The AFP Disaster Response Task Force was created to assist the NDCC at the headquarters level. Corresponding disaster response task groups were also established in every branch (army, navy and air force) and also among unified commands (e.g. the Southern Command). Disaster coordinating centres were also put up, collocating with the RDCCs and serving as advance command posts. These structural changes nevertheless did not create a specialised unit for disaster response; the army battalion or brigade (configured as they were for counterinsurgency operations) nearest the disaster area plus corresponding reserve units and their navy and air force equivalents nearest the disaster area remained the primary responders, as before. What these new arrangements provided was military structures matching the DCCs for better horizontal linkages. These changes also reflected the underlying shift in the military's doctrinal precepts about the importance of disaster response to the military's non-combat counterinsurgency repertoire (Hall 2006). It is widely understood within the ranks that military expertise is no longer necessary only in the application of force to end insurgency, but increasingly in other aspects of governance as well. The military's readiness to undertake non-combat-related activities (including disaster response), which involve dealing with officials,

${ }^{6}$ The AFP's other mission areas are internal security, territorial defence,national development, international defence and security engagement, peacekeeping and command-and-control. 
politicians, civilians, NGOs and the media, is an important component of this strategy (Lim 2004).

In the past years, the Philippine government has accepted foreign military personnel/assets in modest numbers and has relied on ad hoc arrangements to link these up with the DCC framework. This is done primarily through the use of military liaison officers at tactical and strategic levels. Recently, the Philippine and the US militaries, working under the terms of the Visiting Forces Agreement, created the Combined Coordination Center (CCC) framework to better structure the latter's involvement in disaster response in the Philippines (Garcia 2008). Under this framework, the CCC will serve as a focal point for coordination between the two militaries and local civilian agencies. The USA will send a disaster-assessment team as advance party, who alongside a Philippine military liaison officer to the NDCC will comprise the joint assessment team. At the tactical level, the US military will have a task force parallel to the AFP Disaster Response Task Group at the local disaster area. On scene, a CCC comprising of members from each task force (including the assessment team) will jointly undertake tasks related to logistics, civil-military operations and communication. The local forces are also tasked to provide force protection to the foreign military personnel.

The Philippine military has been keenly interested at the prospect of working alongside other foreign counterparts in disaster response. It has participated in many discussions about developing a framework for joint or multinational force cooperation in this non-traditional task. ${ }^{7}$ While these talks have not yielded any common framework for coordinating foreign military involvement, it nevertheless opened opportunities to undertake joint military exercises for this type of operation (e.g. the April 2009 humanitarian assistance for disaster relief exercise featuring the armed forces of ASEAN countries).

In view of the Oslo Guidelines, the AFP in principle is assigned largely a supportive role to the civilian institutions (police, relief agencies), and its tasks are

${ }^{7}$ SAGIP [Tagalog word for rescue] 1999 and 2002 were examples of these formal discussions. In these talks, the participants (initially the USA and Australia, later expanding to 12 countries) sought to develop linkages between national response groups, regional warning centres and multinational forces for disaster response. Concerns were articulated about how foreign military actors could better provide the Philippine government humanitarian assistance within the standard operating time of 72 hours. 
limited to indirect assistance and infrastructure support in response to disasters. Within the AFP, there are ongoing efforts to create structures to facilitate horizontal linkages with the DCCs and to ensure timelier utilisation of ground forces when needed. There also are incipient attempts to concretise foreign military participation in disaster response, at least with the USA, through joint military exercises.

\section{Disaster-coordination framework, tasking and roles}

The response to the Guinsaugon disaster reflected the principle of tiered response or 'levelling up' in which the Philippine DCC is based. Although the Guinsaugon mudslide only affected a village, at the onset the operative framework was that of the PDCC rather than the MDCC. It was generally acknowledged by the municipal government officials that they were not prepared for a disaster of that scale and magnitude (Enage 2008; Lim 2008). Although they were immediately present at the site soon after the mudslide transpired, they were unable to mobilise and act expeditiously.

The Southern Leyte PDCC under the helm of Governor Rosette Lerias took the helm decisively. ${ }^{8}$ The PDCC met at the capitol hours after the disaster was known, and members from the local chapter of the Philippine Red Cross, social welfare officers, ambulances and provincial dump trucks were dispatched. By the evening of Day 1, Governor Lerias convened a joint meeting of the MDCC and PDCC at St Bernard town proper and immediately made two key decisions: (1) evacuate the nearby villages the next day; and (2) divide the general tasks between the search and rescue operations at ground zero and relief operations at the town proper. The 'expanded' PDCC (as they now had regional, national and international participants) met every night for the first two weeks (with members of the media invited). During those meetings, the day's activities, reporting of concerns and the next day's plans were taken up. Among the controversial decisions Governor Lerias had to make was to submit to public demand to bury the bodies and to call a halt in the search and rescue operations, on the basis of scientific advice from other agencies (Lerias 2008). She also acknowledged serious gaps in relief services, including (1) the insufficiency of trauma/counselling services; and (2) the shortage

${ }^{8}$ Governor Lerias claimed that the PDCC was already 'activated' prior to the Guinsaugon mudslide, because landslides have also occurred in several other towns days before. 
of other relief items/services such as underwear, soap, sanitary napkins for the female evacuees and latrines. Given the province's key role, it accepted and maintained its own registry of cash/kind donations separate from that of the town. Although the bulk of the relief assistance eventually went to St Bernard, other items were also equitably distributed to other disaster-afflicted areas in Southern Leyte province. It also mattered that Governor Lerias had a direct link with NDCC chair Rabonza and to President Arroyo soon after, enabling the PDCC's access to national resources (Lerias 2008).

Many departments, local government agencies and NGOs took part in the response. One group were regional offices of key government agencies based in Tacloban City. The DSWD regional office focused on helping the affected LGU run its relief distribution operations and the evacuation centres (Nadera 2008). The regional health office sent volunteers and medicines to St Bernard. They also monitored and addressed the health needs of those at the evacuation centres (Dico 2008). The regional DPWH restored the national road network leading to St Bernard town proper and to ground zero (Veloso 2009). Their dump trucks were also used to haul relief items and cadavers. The regional DENR contributed through its geological hazard assessment studies and field assessments of the various resettlement sites (Nasayao 2008).

The local Philippine Red Cross (PRC) chapter received and transported its own relief items and supplies flown in from Tacloban Airport, and distributed them in St Bernard (Pagasartonga 2008). It managed one evacuation centre and provided medical as well as psychosocial services, including a tracing system for families wishing to find relatives. $\mathrm{RC}$ volunteers helped in the retrieval operations at ground zero, provided cadaver bags and refrigeration for cadaver specimens and gave food to rescuers.

The police, composed of elements from St Bernard, Southern Leyte province and the Region VII mobile group, established a temporary command post that eventually became the permanent command post. Their contribution centred on two aspects: providing security and serving as a documentation hub for all groups coming to render assistance (Enage 2008). With soldiers from the $43^{\text {rd }}$ Infantry Battalion, the police secured the ground zero perimeter and staffed the checkpoints leading to ground zero and the operations centre at the town proper. Some also helped unload and carry relief goods.

The army reservists were mainly utilised for unloading and transporting relief goods, media equipment and cadavers. They were briefly involved in the search and 
rescue operations at ground zero, provided security for the Cristo Rey High School evacuation centre and escorted some NGOs/dignitaries coming to the area.

The local and foreign military contingent concentrated on search and rescue activities at ground zero. Helicopters from the AFP as well as US Marines were used to transport search and rescue personnel to ground zero (from the command post; from their ship USS Essex, which was docked off Anhawan; and even from Tacloban City). Elements from the $43^{\text {rd }}$ Infantry Battalion also worked alongside the police in ensuring security at the site.

As clustered, there was a seeming division of tasks between civilian agencies and institutions versus security forces. The army regulars, reservists and foreign military assets were utilised mainly for search and rescue, transport and providing security (at least on the part of the local police, army and reservists). The civilian actors meanwhile concentrated their efforts on relief provision and running the evacuation centres, with minimal involvement in the search and rescue efforts (limited to cadaver processing).

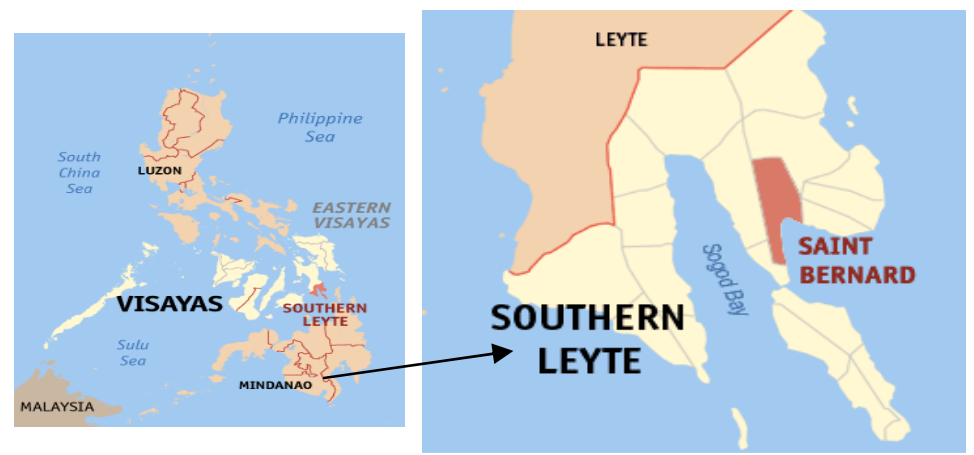


Figure 1: Map of the Philippines and map of Southern Leyte province showing location of St Bernard ${ }^{9}$

Figure 1 shows the location of the St Bernard and Southern Leyte province in the Philippines. There were three major hubs of disaster-related activities. One was Tacloban Airport, where most relief goods and supplies from Manila and overseas were flown in using the Philippine Air Force's C130 plane. From Tacloban, the goods were loaded in trucks for delivery to St Bernard. A second hub of activities was at St Bernard town proper, where the PDCC held its nightly briefings. It was also at the town proper where most relief donations were kept and recorded at a central warehouse. There were five evacuation centres in the town, temporary housing the survivors and evacuees (3 272 in total) from the five threatened villages of Nueva Esperanza, Ayahag, Sug-angon, Magatas and Kauswagan. The third hub was at ground zero (7 kilometres from the town proper) and the Incident Command

\footnotetext{
${ }^{9}$ Available on the internet at http://en.wikipedia.org/wiki/File:Ph_locator_southern_leyte_saint_bernard.png [accessed 28 September 2010].
} 

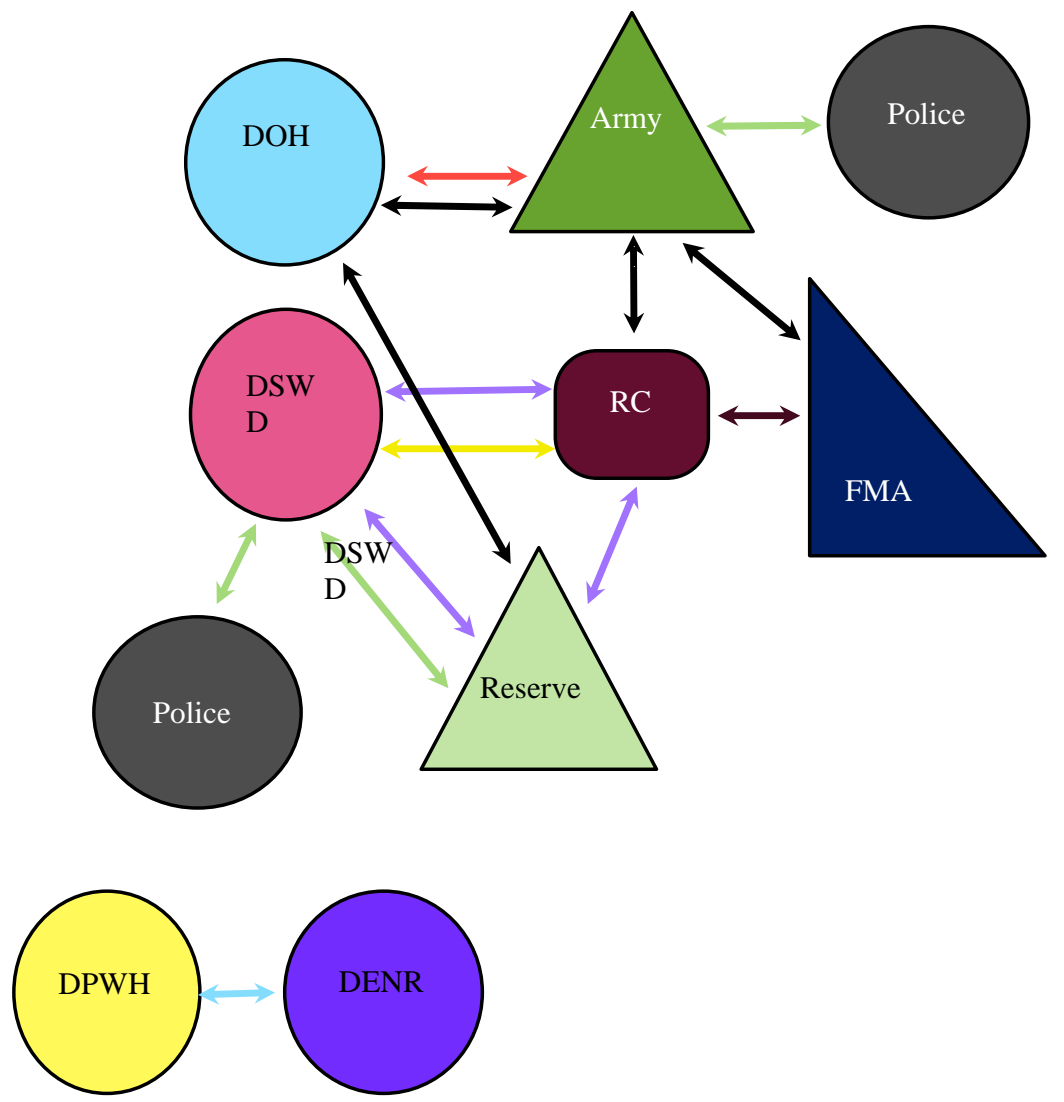

Legend for arrows: search \& rescue (black); relief provision (violet); evacuation centre management (yellow); medical assistance (orange); transport (maroon); infrastructure (blue); security (green)

Figure 2: Coordination matrix among key actors at the disaster site(s) ${ }^{10}$

${ }^{10}$ There were other NGOs and government agencies identified as collaborators (e.g. the National Bureau of Investigation (NBI), Deustche Gesselschaft fur Technische Zusammenarbeit (GTZ), Care and Oxfam, geologists from the University of the Philippines and the Bureau of Mines and Geosciences and two construction firms that provided equipment). 
Post, where groups involved during the search and rescue operations had their makeshift quarters and equipment/vehicles stowed. Because of the continued danger from the unstable grounds, only search and rescue personnel (army regulars, foreign military contingents, scientists and the RC) were allowed on the premises. ${ }^{11}$ The rest of the actors operated at the town proper, doing either relief/medical needs provision or evacuation centre management.

Figure 2 depicts the linkages between the various actors across various tasks. There is denser interface between civilian actors than between civilians and the military. The DSWD, in particular, has many linkages with other groups on account of its involvement in relief provision. Except for the police (which shares security tasks with the military), the $\mathrm{DOH}$ and the RC, much of the military's engagements deal with the other foreign military groups. In fact, the foreign military contingents have only the $\mathrm{RC}$ as civilian link. Between the reserves and the regular army, the former has more civilian connections owing to its presence in search and rescue operations, security and relief goods provision.

\section{Civil-military interface at ground zero and at the town proper}

There were three military groupings involved during the operations: the combat unit, the combat support unit (reservists) and foreign contingents/elements. ${ }^{12}$ The major combat units involved were the $43^{\text {rd }}$ Infantry Battalion, the $19^{\text {th }}$ Infantry Battalion and elements (including medical units) from the $8^{\text {th }}$ Infantry Division. Among the reservists who participated in the operations were (1) ROTC students from Southern Leyte State University; and (2) army reservists from the 8th Regional Community Defense Group . There were several foreign contingents/units present on the ground: 148 US Marines, medical units from Indonesia (est. 30) and Malaysia

${ }^{11}$ The army and police maintained a fairly strict cordon around the disaster site through a system of checkpoints. NGOs were allowed in only if they were bringing food for the rescuers or were members of the media.

${ }^{12}$ Under AFP's rule, the army combat unit and combat support unit whose area of responsibility includes the disaster area are tasked to respond. When this happens, the unit concerned prioritises disaster response above other types of missions, and correspondingly reassigns personnel, equipment and mobility towards this purpose. 
(45), search and rescue teams from Taiwan (33) and Japan (15), and a Spanish canine unit (4). ${ }^{13}$

The mudslide was one of the first well-publicised US military involvements in disaster response in the Philippines. In addition to the small contingent, other units involved were the Forward Deployed Amphibious Ready Group and related airlift and helicopter squadrons that provided logistical support and an advance assessment team from the Guam-based $36^{\text {th }}$ Contingency Response Group. The activities by the US military were as follows: (1) provided forces to assist in search and rescue operations; (2) provided relief supplies, including water cans, bottled water, blankets, military food rations, sleeping mats, pick axes, shovels, rice, medication, diesel fuel drums, chain saws and generators, light sets and kettles; and (3) provided logistics, notably air and ground transportation through fixed wing assets (KC 130 Hercules, C17 Globemaster III) and helicopters (CH-46E, CH 53E Super Stallion, UH-1H Huey and Black Hawks).According to the local reservists we spoke to, the American advanced party arrived on Day 2 and the main ground contingent on Day 3. After the announced end of rescue operations on 25 February, the main US Marine contingent pulled out, but some units stayed on to provide further assistance with recovery and reconstruction. Accounts by the local army indicated that the Americans (and the other foreign contingents/units) were unarmed, and that the local troops escorted the Americans when the latter went to the town proper (Saya-ang 2009).

It is observed that the entry of foreign units into St Bernard followed the Oslo Guidelines principle for foreign assistance to come in where national efforts are insufficient. Their efforts were also largely concentrated in search and rescue operations and logistics support. Even the Americans who also provided relief goods were not directly involved in their distribution. Although the speed at which they were deployed was commendable (the Taiwanese and Malaysian teams arrived on Day 2), the very nature of the disaster and site conditions made the operations particularly difficult. Ground-penetrating scanners and equipment for drilling or moving earth did not prove useful in locating targets. This was one case where international assistance in search and rescue operations had little added value.

${ }^{13}$ Of the approximately 5000 personnel or estimated members of the US military involved, the ground forces was actually a relatively small contingent from the $31^{\text {st }}$ Marine Expeditionary Unit (US Department of Defense 2009; Esguerra, Arnaiz and Napallacan 2006). 
The response to the Guinsaugon mudslide illustrates the fluid distinction between what is 'military' versus 'civilian' in this type of operation. Except for the US contingent, it is not certain whether the other foreign units were 'military' in composition. In some countries, search and rescue teams are composite teams of civilians - often police officers and fire fighters. In terms of the local army unit, the combat unit and reservists also reflect this ambiguity. In terms of uniform and general appearance, the two units are alike, except that the latter are part-time soldiers, locals and have pre-existing connections with the local government. As legally envisioned, the reserve corps assists the military in a variety of tasks, including national defence and disaster response. The ROTC members at local universities/colleges constitute another pool of these reservists. Unlike members of the army combat units, the reservists consider themselves more 'civilian' and as an organisation, embedded into a civilian framework in disaster response. The army combat unit, by contrast, has a different nature and orientation. It is organisationally removed from civilian life and has fewer opportunities to interface with local civilian authorities/agencies across its seven mandated tasks. Nevertheless, given Southern Leyte's previous experience with disasters, the army units were deployed and worked side by side with civilian agencies/authorities.

The way in which the $43^{\text {rd }}$ Infantry Battalion and reservists operated on the ground further illustrates these differences in character. Both were alike in the speed at which they can mobilise and deploy, but varied greatly in terms of their preparation, approaches and modalities of dealing with civilian agencies/authorities. The reservists mobilised two companies immediately after receiving a direct message from Governor Lerias. They used the municipal offices as staging point and relied on the transportation provided by the municipal and provincial governments to get them to the disaster site. Like the army, they carried provisions (rice, noodles, canned sardines and cooking pots) but were nevertheless ill-prepared for the lengthy deployment. They first made a courtesy call to the St Bernard mayor before proceeding to ground zero. The reservists were only involved in search and rescue operations for two days, after which they relocated to the town proper, where they subsequently established their quarters. By contrast, the $43^{\text {rd }}$ Infantry Battalion first deployed a company, then a larger contingent on the same day, using their own vehicles. As a self-contained outfit, those deployed brought standard issue for disaster response (shovel, rope and flashlight) as well as three to five days' food provision. Unlike the reservists, the army unit was much more used to lengthy deployment with the barest minimum and used to rough conditions for work and quartering. In terms of procedure, the army unit proceeded directly to the site and 
stayed on the site for the remainder of the mission which lasted one month (Sayaang 2009).

In terms of activities, there is little overlap between the tasks of the reservists and the combat unit. In the first two days of relative confusion, all hands (ROTC students, $43^{\text {rd }}$ Infantry Battalion, reservists and even locals) dug and pulled out dead bodies/body parts, delivered them to collection points, and washed and facilitated the identification of the remains. However, after tasking had been issued by the PDCC, the reservists relocated to the town proper, where they became involved in carrying relief goods from the pier to the central warehouse, assisting NGOs and the local social welfare office in distributing relief goods, securing the evacuation centres, and transporting, burying, exhuming and re-burying the cadavers (Tio 2008). By contrast, the $43^{\text {rd }}$ Infantry Battalion's activities were all centred at ground zero. A platoon was assigned to retrieval operations (with the processing of cadavers thereupon done by the $8^{\text {th }}$ Infantry Division medical team), while another was tasked to secure the perimeter (Adal 2009). The army's key concern was looting and indiscriminate entry of non-search and rescue personnel and their vehicles. For this purpose, the army staff manned an advance post and registered those going to the site. Off-site, some elements were also involved in transporting gas for the helicopter from the Philippine Navy ship docked at St Bernard, securing relief goods at the warehouse and transporting evacuees to the town proper.

The reservists interfaced with more civilian agencies and NGOs than did the combat personnel. When queried about whom they worked with, the reservists listed the municipal and provincial social welfare office, the regional DSWD, the DOH (which provided lime and body bags for the cadavers), the NBI (which examined the exhumed corpses) and NGOs (such as the Kapuso Foundation, Sagip Kapamilya, GTZ, Plan Philippines and the Philippine Red Cross). They also identified having worked with the Philippine Navy (in carrying relief items) and the US Marines. By contrast, the combat unit identified having worked alongside US Marines during the retrieval operations centred at finding Guinsaugon village's elementary school, and Indonesian and Malaysian medical units that stayed on to conduct their own medical mission. Their manner of engagement with those visiting ground zero was less substantive - often as guides or as escorts to ensure that visitors do not stray into prohibited areas.

Engagements at a formal level (i.e. between Governor Lerias and the army/reservist officers) reflect the civilian leader's reliance on the military units. Governor Lerias, although at the helm of the on-site emergency operation structure, 
appointed military figures to lead activities in the four staging areas, namely Brigadier General Oscar Randy Dauz of the $8^{\text {th }}$ Infantry Division with an Advance Command Post in Tacloban Airport; Commander General Bonifacio Ramos, superseding $802^{\text {nd }}$ Brigade Deputy Commander Colonel Nestor Sadiarin with Emergency Operation Centre at St Bernard in charge of search and rescue operations; $43^{\text {rd }}$ Infantry Battalion Commanding Officer Colonel Raul Farnacio, in charge of retrieval operations; and $8^{\text {th }}$ Regional Community Defense Group Commanding Officer Colonel Manuel Marcon Jr., in charge of relief and recovery operations. Following the idea of an incident command system, Governor Lerias designated General Bonifacio Ramos to be the on-scene commander at ground zero. ${ }^{14}$ In some ways, the selection of military units as lead organisations for response activities was unprecedented. However, because of the numerical dominance of military units (foreign and local) in these tasks, it probably made practical sense. This also allowed a clear demarcation between the broader work of the 'civilian' PDCC, which was to coordinate more long-term concerns such as relief operations and rehabilitation initiatives.

In terms of search and rescue and retrieval operations, there was no question among the respondents of this research as to the military being in charge. As incident commander, General Ramos declared ground zeroas a no-fly zone and designated tasks and assigned locations to various groups inside ground zero. For instance, some army units had work posts alongside the US Marines, while others were closer to the mountain range. The RC personnel were mostly at the perimeter, waiting to receive bodies that were dug up. However, it was not clear from the data gathered among the various civilian agencies whether the $8^{\text {th }}$ Regional Community Defense Group acted as a 'cluster' representative of the relief and recovery operations. The reservists were involved in this capacity, but their engagements with the DSWD personnel and local officials as described did not picture leadership.

\section{Issues}

${ }^{14}$ According to Colonel JuvymaxUy (2009), it is standard for the AFP to elevate command over an operation "one-level-up" (meaning at the brigade, rather than battalion level), given the multiplicity of units and officers involved. This also follows the procedure where foreign military contingents are present. The brigade then also represents the AFP viz. the US Marines in the CCC. 
In the annals of Philippine disasters, the response to the Guinsaugon mudslide exhibited the level of institutional maturity of local authorities and agencies, which over the years of disaster experience have developed unique operational systems. It also depicted the continuing challenges of coordination across departments as well as the limitations in logistics and equipment when it comes to search and rescue operations versus the relative sophistication in the way relief operations are carried out. The disaster response also revealed the continuing centrality of the armed forces in at least two areas: search and rescue and transporting relief operations. The presence of foreign military units in a disaster of such scale also portends to future trends of similar international deployment/hosting, thus adding another dimension to the coordination challenges in disaster response. Except for the US Marines, who belonged to an expeditionary unit, the other foreign participants were either search and rescue or medical teams. This is suggestive of an international preference for easily deployable, smaller, self-contained and task-specific units.

Some civilian actors have fairly developed standard operating procedures for deploying for disaster response. For instance, the DOH and DSWD have standby personnel ready to be pulled out for immediate deployment; both also have standard issue (in term of equipment, supplies and relief goods) to bring with them and a dedicated vehicle for that purpose. The DSWD had developed niche capabilities in relief goods management (warehousing, inventory, and distribution), evacuation centre management, tracing systems and dealing especially with orphans from disasters. The same cannot be argued for the DENR and DPWH, given their scant experience in these types of operations. Yet gaps were also evident in terms of needs matching at the deployment-preparation phase and logistics management. Often, teams brought in supplies but failed to account fully how they were used at the completion of operations. How and to whom the tons of donations in kind (many of which were non-consumables) were eventually distributed became a source of friction between the local and provincial governments.

The lengthy deployment of civilian personnel and the increased demand for communication facilities are related concerns. Any type of disaster operation that brings in additional people creates an additional burden on local capacities. The disaster created an artificial demand for housing and ancillary services, and also increased the demand for communication facilities, as various actors were pressed to write and submit reports. Many government agencies present had to rely on the communication assets available at the municipal hall (telephones, fax machines, computers with internet access), creating a long queue and considerable wear and tear on their local host's equipment. In order to complete their reports, the various 
regional offices had to rely on local bureaucrats to assist them, who otherwise could not deliver because they were victims themselves.

The disaster response at St Bernard illustrates how poorly equipped the local military is for search and rescue operations when compared to their foreign counterparts. The standard issue for such operations consists only of a shovel, rope and flashlight. There were a limited number of masks and gloves, and those involved in retrieval operations did not have waterproof boots or any type of protective gear. Contrary to expectations in most literature, the Philippine military does not have as many air assets necessary for these types of operations. At that time, two serviceable C130 cargo planes and several vintage Vietnam War-era helicopters were used for long and short hauls. By contrast, the Americans deployed many fixed wing aircraft and helicopters to transport relief goods, supplies and personnel from Tacloban to St Bernard, within ground zero and from their ship to the disaster site. While the army used a shovel bulldozer to transport their men across the river from the command post to ground zero, the Americans used a helicopter for this short commute. The American military also operated at night, equipped as they were with lights powered by their own generator sets. At the town proper, the Americans also set up their own satellite communication facility.

Vertical linkages (at intra-departmental level) were quite strong. For instance, various units under the $8^{\text {th }}$ Infantry Division contributed military personnel for various tasks, including health monitoring and logistics. Among the civilians, the regional DSWD worked with its counterparts from other regions in assisting municipal and provincial social welfare officers in designing systems to manage relief items inventory and distribution and evacuation centres. Regional offices submitted periodic reports to their national offices of their activities and updates on the ground. Horizontal/interdepartmental linkages, by contrast, were weak and ad hoc. There were only a few cases reported where departments worked alongside each other. One of this was when the $8^{\text {th }}$ Infantry Division medical team reported a case of chicken pox outbreak in one evacuation centre to the $\mathrm{DOH}$, enabling the latter to take the necessary precautions to prevent an outbreak. Conflicts between various actors were also present over tasking, as in the inconsistent tallies of body counts between the DOH and the RC (both were apparently counting at different collection points) and the row between the DOH and NBI about whether to bury the cadavers straight away or not in order to allow for genetic identification. There were also concerns about quartering, with some foreign contingents complaining over the US Marines taking over a fair amount of space in the incident command post area. 


\section{Analysis and conclusion}

The military's involvement in disaster response operations is a function of legal and normative principles, which can vary greatly from country to country. In the Philippines, the DCC, in place since the 1970s, vests in the armed forces a legitimate role in disaster response and provides a framework for civil-military engagement, although the 'civilian' component is only restricted to elected government officials and public agencies. Recurring disaster events, in turn, has provided a historical basis for this engagement, leading to a more or less clear acceptance of the following normative points: (a) that the armed forces takes policy direction from the civilian authority (whether the NDCC chief, the governor or the mayor) on deployment, activities, tasking, reporting procedures and timetables (including pullout of troops from the site); and (b) that disaster response, although a secondary military task, is nevertheless vital in meeting the military's strategic goals in the affected area. Hence, as asserted by Desch (1996) and Goodman (1996), the Philippine armed forces' participation in disaster response generates little controversy, largely owing to these normative meeting points. There was no tension between the governor's uncontested legitimacy in making crucial decisions concerning tasking and deployment, and her recognition of and reliance on military expertise in organising an effective response (as evident in the designation of military officers to lead mixed [military and civilian alike] groups in various staging areas). In addition, it was not an issue for public health personnel to share with the military the task of providing medical services to evacuees. Having uniformed personnel assist in relief goods delivery is commonplace.

That said, no such norms are observed in the case of local civilian-foreign military interface. Although there were already national structures in place to receive foreign and civilian military assistance in emergency relief, the St Bernard case illustrated that locally, engagements proceeded in an ad hoc fashion. Dealings between the local authorities and the foreign military groups were for the most part mediated by Philippine military liaisons. In the absence of clear guidelines as to how the local disaster manager (the governor of the affected province) was supposed to deal with foreign troops, tensions were avoided by confining them to ground zero and to search and rescue operations. By limiting the foreign troops' movement and activity, the local civilian authorities managed to avoid many of the sensitive questions associated with hosting foreign troops in population centres. The St Bernard case also illustrated the mismatch between foreign assistance offered and what was needed. On one hand, US military assets clearly provided added value in 
terms of transporting relief goods and personnel, but mattered little in the search and rescue operations (as did the other foreign composite teams).

The St Bernard case likewise points to how the complex structure of the Philippine and foreign armed forces creates a more nuanced civil-military engagement. Locally, the distinction between combat, combat support and noncombat units within the same area of operations engender different modalities of engagement with civilian actors. Reservists from non-combat units are found to be more cognisant of reporting procedures vis-à-vis local authorities in the event of a disaster, and have denser linkages with civilian actors prior to the disaster event, although they are less self-sufficient for longer periods of deployment. By contrast, combat units are more self-sufficient, although they are poorly equipped for these types of operations (not surprising again, given the institution's counterinsurgency thrust). While St Bernard itself was not an active insurgency area, force protection (particularly of the foreign troops) was foremost in their minds. The varying composition of the foreign units (pure military versus mixed civilian/military units, teams versus contingent) also created different challenges to hosting communities.

Engagements between civil servants and the military were limited owing to the separation of tasks and area of activities. Most civil servants (from the social welfare and health departments) were in the town centre, while the bulk of the military personnel were at ground zero. As most NGOs carried out relief activities, they also had little interface with the military (with the exception of the Philippine Red Cross, which alone was allowed at ground zero). In effect, the actors were distributed into parallel streams of relief provision (mostly civilian) and search and rescue/retrieval (mostly military), with hardly any reason for information sharing or collaboration, except for logistics (moving relief goods and personnel). Whether by design or purpose, the disaster response set-up at St Bernard effectively avoided 'competition' between the military on one hand and NGOs and civil servants on the other hand.

This case study points to what will be the future trend of local hosting for foreign disaster responders and the need for concrete guidelines beyond those provided under the Oslo Guidelines. The Oslo Guidelines assume disasters are of a national rather than a local scope and are oblivious of the different security ecologies affected communities face (i.e. whether or not the area has an active insurgency problem). In a localised disaster, local governments bear the burden of hosting multiple actors with varying capabilities and assets, which it must try to coordinate under a framework (DCC), which for the most part does not articulate how foreign elements are to 'plugged in'. Where and under what circumstances foreign military 
assistance should be accepted remains a decision by the national government, with scaling and matching (if and when it happens) mediated by the local military units liaising between them and the local government hosts. The confinement of foreign military contribution to the same tasks and spatial assignment as their local military counterpart serves to diffuse contacts with civilian populations and organisations.

For further studies on the international angle of civil-military engagement in disaster response, the authors recommend interviews with foreign military participants to explore their concerns and identified challenges relating to this operation type. Queries should include how consultations with the local civilian hosts are done (formally within the established coordinating framework or informally) on matters such as tasks, duration of deployment and pullout, quartering, troop movement (i.e. are they to be restricted or confined to certain areas within the disaster site) and force protection. The rules of engagement (either standing or shortly agreed upon prior to deployment) with the local civilian population, other foreign military units and civilian groups at the site are also worth examining. Included in these queries are sensitive concerns such as the carrying of firearms and civilian access to foreign military assets or equipment.

\section{References}

Adal, G.A. 2009.Comments during the focus group discussion of the $43^{\text {rd }}$ Infantry Battalion at Camp Gen. Climaco Pintoy, Suarez, Iligan City, 7 June.

Carter, W.N. 1991. Disaster management: A disaster manager's handbook. Manila: Asian Development Bank.

Desch, M. 1996. Threat environments and military missions. In L. Diamond \& M. Plattner (eds.). Civil-military relations and democracy. Baltimore: John Hopkins University Press: 12-29.

Dico, F. 2008. Personal interview. Department of Health, Region 8, Palo, Leyte, 9 August.

Enage, H.F. 2008. Personal interview. St Bernard, Southern Leyte, 11 August.

Esguerra, C., Arnaiz, J. and Napallacan J. Heavy rains stop the search; school roof believed found. 2006. Philippine Daily Inquirer [Electronic], 24 February. Available at <http://www.inquirer.net/specialfeatures/leytelandslide/view.php?db=0\&arti cle $=20060224-67248>$ [accessed 22 June 2009]. 
Frerks, G. 2008. Tsunami response in Sri Lanka: Civil-military cooperation in a conflictuous context. In S.J.H. Rietjens \& M.T.I.B. Bollen (eds.). Managing civil-military cooperation: A 24/7joint effort for stability. Hampshire: Ashgate: 67-80.

Garcia, G. 2008. Personal interview. AFP Security Engagement Board, Camp Aguinaldo, Quezon City, 8 August.

Goodman, L. 1996. Military roles: Past and present. In L. Diamond \& M. Plattner (eds.). Civil-military relations and democracy. Baltimore: John Hopkins University Press: 30-43.

Hall, R. 2004. Exploring new roles for the Philippine military: Implications for civilian supremacy. Philippine Political Science Journal 25(48): 107-130.

Hall, R. 2006. Politics in the frontline: Local civil-military interactions in communist counterinsurgency operations in the Philippines. Philippine Political Science Journal 27(50): 1-30.

Lerias, R. 2008. Personal interview. Maasin, Southern Leyte, 13 September.

Lim, B. 2004. AFP's expanding role in the Philippine society. Speech delivered during the First Philippine Army Senior Leaders Conference. Philippine Army Officers Clubhouse, Fort Bonifacio, Makati City, 18-19 March.

Lim, M. 2008. Personal interview. St Bernard, Southern Leyte, 9 July.

Lupig-Alced, M., Arcilla, M.J., Dulce, C.B. Jr. \&Elegado, E.B. 2005. A study on current disaster management practice and opportunities for strengthening local communities. Pasay City: CARE Philippines.

Mandel, R. 2002. Security and natural disasters. Journal of Conflict Studies 22(2): 181-197.

Memorandum of Understanding for International Humanitarian Assistance. Signed on 15 February 2007. Available at <http://210.185.184.53/ndccWeb/images/ndccWeb/status_don_funds/ihan\% 20mou.pdf $>$ [accessed 13 May 2009].

Nadera, P. 2008. Personal interview.Department of Social Work and Development Region 8, Tacloban City, 8 August.

Nasayao , E. 2008. Personal interview. Department of Environment and Natural Resources Region 8, Tacloban City, 8 August. 
National Disaster Coordinating Council.2006. Executive summary of the landslide incident in StBernard, Southern Leyte, March 22. Camp Aguinaldo, Quezon City.

Office of the Governor of Southern Leyte. 2006. Oplan Kinabukasan Meeting: Official minutes, 10 March.

Pagasartonga, M. 2008. Personal interview. Philippine Red Cross Tacloban, Leyte Chapter, Tacloban City, 8 August.

Quilop, R. 2008. Military personnel beyond traditional roles: Peace operations and disaster response. Paper presented at the Workshop on Civil-Military Cooperation in Emergency Relief, Tokyo, Japan,21-22 January.

Saya-ang, J.D.A. 2009. Comments during the focus group discussion of the $43^{\text {rd }}$ Infantry Battalion at Camp Gen. Climaco Pintoy, Suarez, Iligan City, 7 June.

Schulze, K. 2005. Betweenconflict and peace: Tsunami aid and reconstruction in Aceh. Available at <http://www.lse.ac.uk/Depts/global/Publications/HumanSecurityReport/Tsu nami/Aceh\%20Tsunami\%20 Response.pdf> [accessed 20 April 2009].

Tio, S. Jr. 2008. Comments during the focus group discussion of the 8th Regional Community Defense Group,Maasin, Southern Leyte, 10 August.

US Department of Defense. 2006. US forces help victims of Leyte Island landslide. Available at <http://www.defenselink.mil/home/features/Leyte/landslide> [accessed 22 June 2009].

Uy, J. 2009. Personal interview. Camp General ClimacoPintoy, Brgy. Suarez, Iligan City, 7 June.

Veloso, C. 2009. Personal interview. Tacloban City, 15 March.

Wiharta, S., Ahmad, H., Haine, J.-Y., Lofgren, J. \&Randall, T. 2008. The effectiveness of military assets in natural disaster response. SIPRI: Solna, Sweden. 